\title{
Silicon carbide power device characteristics, applications and challenges: an overview
}

\author{
Muhamad Faizal Yaakub', Mohd Amran Mohd Radzi², Faridah Hanim Mohd Noh ${ }^{3}$, Maaspaliza Azri ${ }^{4}$ \\ ${ }^{1}$ Fakulti Teknologi Kejuruteraan Elektrik dan Elektronik, Universiti Teknikal Malaysia Melaka, Malaysia \\ ${ }_{1,2}^{1,2}$ Fakulti Kejuruteraan, Universiti Putra Malaysia, Malaysia \\ ${ }^{3}$ Fakulti Teknologi Kejuruteraan, Universiti Tun Hussein Onn Malaysia, Malaysia \\ ${ }^{1,4}$ Centre for Robotics \& Industrial Automation, Universiti Teknikal Malaysia Melaka, Malaysia \\ ${ }^{1,2}$ Advanced Lightning, Power and Energy Research Centre, Universiti Putra Malaysia, Malaysia
}

\section{Article Info}

Article history:

Received Jan 17, 2019

Revised Jul 22, 2019

Accepted Aug 3, 2019

\section{Keywords:}

Silicon carbide power device

Silicon power device

Power device material

\begin{abstract}
Silicon $(\mathrm{Si})$ based power devices have been employed in most high power applications since decades ago. However, nowadays, most major applications demand higher efficiency and power density due to various reasons. The previously well-known $\mathrm{Si}$ devices, unfortunately, have reached their performance limitation to cover all those requirements. Therefore, Silicon Carbide $(\mathrm{SiC})$ with its unique and astonishing characteristic has gained huge attention, particularly in the power electronics field. Comparing both, SiC presents a remarkable ability to enhance overall system performance and the transition from $\mathrm{Si}$ to $\mathrm{SiC}$ is crucial. With regard to its importance, this paper provides an overview of the characteristics, advantages, and outstanding capabilities in various application for $\mathrm{SiC}$ devices. Furthermore, it is also important to disclose the system design challenges, which are discussed at the end of the paper.
\end{abstract}

This is an open access article under the CC BY-SA license.

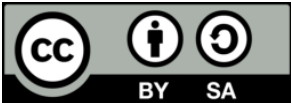

\section{Corresponding Author:}

Muhamad Faizal Yaakub,

Fakulti Kejururteraan,

Universiti Putra Malaysia,

Serdang, Selangor, Malaysia.

Email: muhamadfaizal@utem.edu.my

\section{INTRODUCTION}

In recent decades, power electronics have gained high interest due to new materials invented for the new power devices. Ever since the silicon $(\mathrm{Si})$ based device was created, the innovation in power device materials has been evolved to meet the application requirement and performance needs in various fields[1]. Up till now, the advancement is predominantly driven by the Si power devices such as an insulated-gate bipolar transistor (IGBT) for high voltage, high power, and low-frequency application, and power metaloxide-field-effect transistor (MOSFET) which are particularly targeted for low voltage, low power, and highfrequency application. While MOSFET which is based on the trench gate structure dominates the global market for applications below $600 \mathrm{~V}$, its super junction version (SJ-MOSFET) and IGBT based on field stop and injection enhancement concept have secured the market shares for application in the range from $600 \mathrm{~V}$ to $6.5 \mathrm{kV}$. Even with these advancements, the Si power device has reached its performance limitation. To date, the most high-end Si IGBT breakdown voltage capability is only $6.5 \mathrm{kV}$ with limited switching performance. Furthermore, there is no Si device could operate above $200^{\circ} \mathrm{C}[2]$.

Owning these restrictions, power converter efficiency is reduced severely which leads to the needs of a complex cooling system and expensive passive components. As a result, an upgraded material power 
device is expected. The exploration of the solution to the silicon limitation leads to the investigation of a wide bandgap (WBG) semiconductor materials. The advancement in WBG semiconductor material has made it possible to improve the efficiency of electric energy transformation. Having a trade-off between process/manufacturing maturity, theoretical characteristics, and commercial marketability, Silicon Carbide (SiC) and Gallium Nitride $(\mathrm{GaN})$ are becoming perfect semiconductor material candidates for the next generation of power devices. Despite offering decent high-frequency and high-voltage performance, GaN comes with inferior thermal conductivity and a lack of good-quality bulk substrates required for vertical devices. Consequently, it makes $\mathrm{SiC}$ become a better option for power device material [3], [4]. Nevertheless, GaN-based power devices are still being used and play a major role in other specific applications.

Therefore, due to the interesting features of the SiC power device, this paper presents an overview of the SiC power device and its contribution to the improvement in the state-of-the-art selected applications. $\mathrm{SiC}$ properties and their characteristics are presented in section 2. Adaptation in applications and their contribution to enhancing the overall system performance is discussed and summarized in section 3 . In addition, the system design challenges of $\mathrm{SiC}$ are summarized in section 4 .

\section{THE CHARACTERISTICS}

Recent trend discloses that Silicon Carbide (SiC) based power device has established its popularity among power electronics practitioners in modern applications. Since Infineon introduced SiC Schottky diode back in 2001, the SiC-based power device has kept its momentum in technology development and market growth as projected by [3] depicted in Figure 1. This is due to the fact that the properties and characteristics are well suited to solve innumerable power electronics-related problems and performance demands. From the application perspectives, the most advantageous features of $\mathrm{SiC}$, compared to $\mathrm{Si}$ are the breakdown field, its higher conductivity, and its wide bandgaps as tabulated in Table 1.

In principle, the $\mathrm{SiC}$ scored a breakdown field ten times higher compared to what Si has. Therefore, the thinner drift layer and higher doping concentration can be used on the $\mathrm{SiC}$ power devices at the same blocking voltage. As depicted in Figure 2, SiC power devices such as Unipolar Schottky diodes and MOSFET would have lower specific on-resistance compared to Si counterpart by having thinner blocking layer and higher doping concentration [5]. As a WBG material, it offers other incredible material properties that are attractive to power device design and development. WBG semiconductor material such as $\mathrm{SiC}$, in particular, has advantages of operating in higher temperatures and greater radiation hardening. Theoretically, the thermal energy of the electron valance band is directly proportional to the temperature. As such, it has enough energy to propagate to the conduction band at a certain temperature. But, this uncontrolled conduction event must be avoided. For Si-based material, this could occur around $150^{\circ} \mathrm{C}$ [6], [7]. In contrast, bandgap energy is higher in WBG semiconductor material, as such, more thermal energy is required by the valence electron to travel to the conduction band. Remarkably, for SiC this intrinsic temperature is about $900^{\circ} \mathrm{C}$. The aforementioned argument is also valid for radiation hardening. Radiation energy likewise can stimulate an electron like the thermal energy and make it travel to the conduction band. Consequently, devices developed based on WBG material such as $\mathrm{SiC}$ can endure more in extreme heat and radiation without sacrificing its delightful characteristic [11].

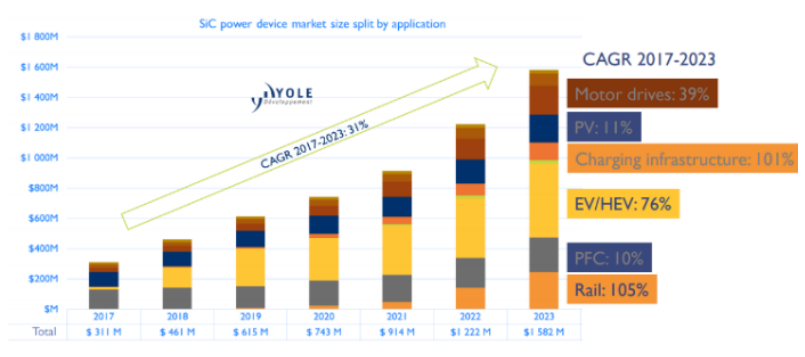

Figure 1. SiC power device market size split by application [3]

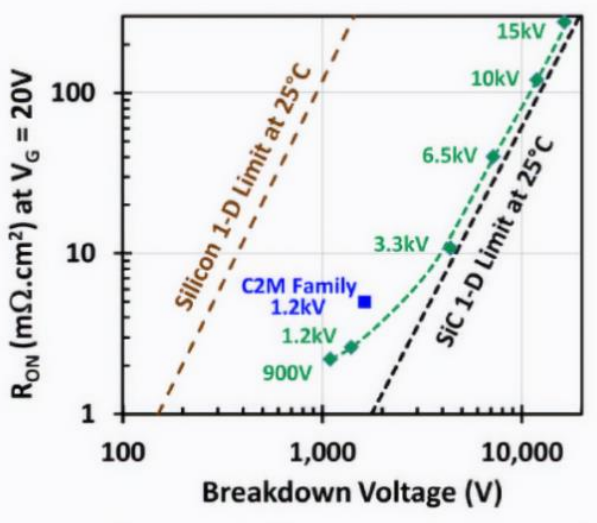

Figure 2. Specific ON-resistance (RON) of SiC and $\mathrm{Si}[8]$ 


\begin{tabular}{|c|c|c|c|c|}
\hline Properties & $\mathrm{Si}$ & $3 \mathrm{H}-\mathrm{SiC}$ & $4 \mathrm{H}-\mathrm{SiC}$ & $6 \mathrm{H}-\mathrm{SiC}$ \\
\hline Energy Gap, eV & 1.12 & 2.4 & 3.26 & 3.03 \\
\hline Electron Mobility, $\mathrm{cm}^{2} / \mathrm{Vs}$ & 1400 & 800 & 900 & 370 \\
\hline Hole Mobility, $\mathrm{cm}^{2} / \mathrm{Vs}$ & 600 & 40 & 100 & 90 \\
\hline Breakdown Field, V/cm $\cdot 10^{6}$ & 0.3 & 4 & 3 & 3 \\
\hline Thermal Conductivity, $\mathrm{W} / \mathrm{cm}^{\circ} \mathrm{C}$ & 1.5 & 3.2 & 4.9 & 4.9 \\
\hline Saturation Drift Velocity, $\mathrm{cm} / \mathrm{s}$ & 1 & 2.5 & 2.7 & 2 \\
\hline
\end{tabular}

In principle, as the drift velocity of the semiconductor increases, the switching frequency capability is also increased. The drift velocities of $\mathrm{SiC}$ semiconductor material are more than twice the velocity of $\mathrm{Si}$ as shown in Table 1. Higher drift velocity permits the minority carriers to be removed faster from the depletion region at the moment of turn-off transient. As such the SiC's switching speed is faster due to the higher electron saturated drift velocity. Additionally, the increased switching frequency is also contributed by the lower on-resistance at the same breakdown voltage of the $\mathrm{SiC}$ semiconductor material. The junction capacitance of the $\mathrm{SiC}$ devices e.g. MOSFET is lower than the Si devices, taking into account trade-offs between thinner drift regions and smaller dice size [12]. Furthermore, numbers of Coss and Qg of SiC material are lower compared to in the $\mathrm{Si}$, which makes $\mathrm{SiC}$ device able to switch at much higher dv/dt. Figure 3 depicts high-frequency switching produced by SiC MOSFET compared to Si IGBT, which offers low switching loss and thus enhancing the converter power density and efficiency [13].

\section{SiC APPLICATIONS}

\subsection{Electric vehicle/hybrid electric vehicle}

At the beginning of 2013, the electric vehicle (EV) market shares cover $0.02 \%$ of the total passenger car segment [14]. However, it is projected that there will be over 600 million cars will be on the road due to strong policies worldwide, and by 2030 , it is estimated that passenger EV will secure $50 \%$ of market shares [15], [16]. 32\% reduction in size and $40 \%$ of reduction in weight and loss of the EV electronics circuit is expected as per an announcement made by The EV Everywhere Challenge in 2013. This will be only possible with the deployment of $\mathrm{SiC}$ devices in the circuit design [17]. Numerous research and development activities have been conducted globally. For instance, in Japan, Denso Corporation has developed 100A SiCMOSFET with the SiC- Schottky Barrier Diode (SiC-SBD) inverter module back in 2007. Later in 2008, NISSAN has introduced to the market an inverter with SiC diode for fuel cell vehicle (FCV). ROHM in collaboration with Honda also developed a 1200V 230A high power inverter module. SiC-SBD and SiCMOSFET have been adopted by them in the design with an integrated three-phase inverter and one phase converter module. As a result, a $25 \%$ reduction of switching loss can be offered compared to the $\mathrm{Si}$ version [18]. A year after that, Mitsubishi Electric has introduced $11 \mathrm{~kW}$ inverter. The inverter module comes with SiC-MOSFET and SiC-SBD on-board and produces $70 \%$ and $75 \%$ loss and volume reduction, respectively [19]. The race of research and development of $\mathrm{SiC}$ power devices for EV application continues as demand increases, not only by introducing new devices but also in improving the quality and reliability of existing technology. This is true when Toyota Corporation has put $\mathrm{SiC}$ power technology into trial on its hybrid Camry and fuel cell bus in 2015 [20]. Figure 4 shows the SiC power control unit developed by Toyota. Table 2 summarizes the research and development of $\mathrm{SiC}$ based power device and module for EV application.
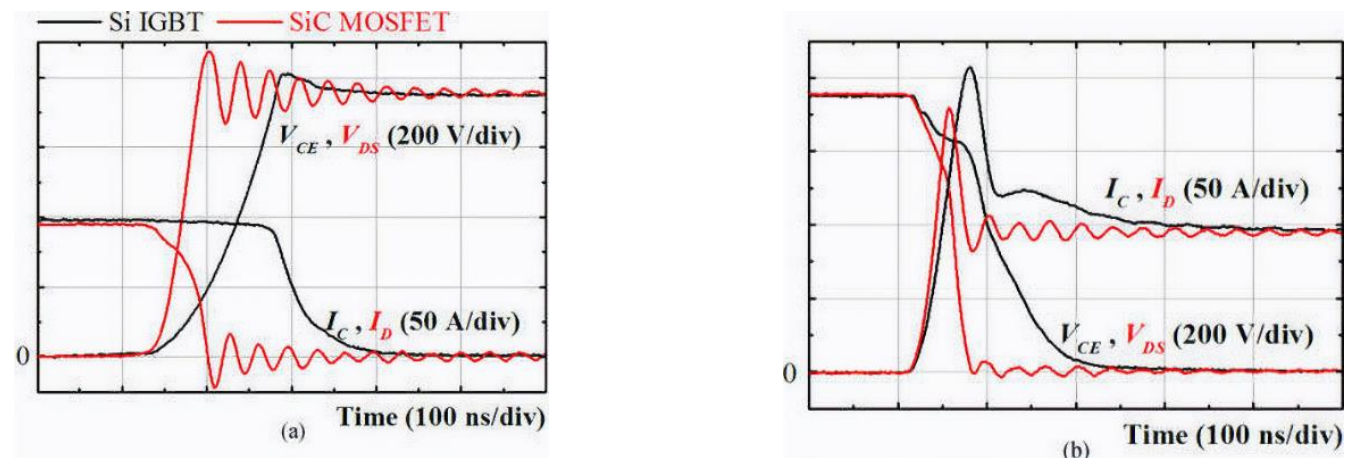

Figure 3. Si IGBT versus SiC MOSFET switching waveform: (a) turn-off and (b) turn-on. [13] 


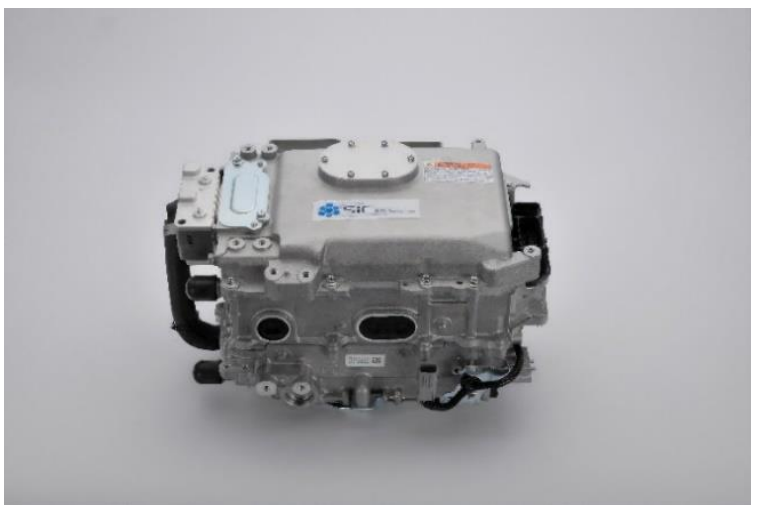

Figure 4. SiC power control unit by Toyota [20]

Table 2: Summary of related research/development Of Sic devices in Ev/Hev applications

\begin{tabular}{|c|c|c|c|}
\hline $\begin{array}{l}\text { Commercial } \\
\text { or R\&D } \\
\text { Year }\end{array}$ & Developer/Researcher & Specification/performance & Approach \\
\hline $2008[21]$ & $\begin{array}{l}\text { Hui Zhang et.al, The } \\
\text { University of Tennessee }\end{array}$ & $\begin{array}{l}\text { System efficiency improvement by } 18.8 \% \text { and } \\
\text { energy loss in motor decreased by } 51.3 \% \text { in HEV. } \\
\text { System efficiency improvement by } 27.7 \% \text { and } \\
\text { energy loss in motor decreased by } 76.2 \% \text { in PHEV. }\end{array}$ & $\begin{array}{l}\text { 1200V 14A SiC JFETs, } 1200 \\
\text { V/ 10A SiC Schottky Diode }\end{array}$ \\
\hline 2010 [22] & $\begin{array}{l}\text { M. Chinthavali et.al, Oak } \\
\text { Ridge National Laboratory, }\end{array}$ & $\begin{array}{l}\text { Inverter efficiency }>98 \% \text { at a power level up to } 8 \mathrm{~kW} \\
\text { at } 10 \mathrm{kHz} \text { switching frequency. }\end{array}$ & $\begin{array}{l}\text { 1200V/ 10A SiC JFET and } \\
\text { Schottky diode module }\end{array}$ \\
\hline
\end{tabular}

2015 [23] Ming Suet.al, Ford Motor Predicted overall switching loss reduction of around Company $40 \%$ on Ford HEV

2016 [24] Dhrubo Rahman, North Peak efficiency for the inverter stage is Carolina State University

2017 [25] Fumio, Wada et.al, Mitsubishi Electric Corp

2017 [26] Jun Liu et.al, Chinese Academy of Science

2017 [27] F. Alfaris et.al, North Carolina State University approximately $99 \%$

Total power loss reduction about $62 \%$ compared to Si.

The power density of the inverter was $14.8 \mathrm{kw} / \mathrm{L}$ and the power-to-weight ratio reached to $10.5 \mathrm{KW} / \mathrm{Kg}$ The current ripple at high frequency reduced from $37 \mathrm{~A}$ to $32.8 \mathrm{~A}$. Output phase current THD yields $2.7 \%$ compared to $\mathrm{Si}(5.3 \%)$. Reduction to the Znetwork element.

2017 [28] W.Zhou et.al, Zhejiang University

Converter efficiency at full load is about $97.7 \%$

900V SiC MOSFET

CREE SiC 6-pack module

1200V/ 300A SiC J1-Series

600V/ 20A SiC SBD

1200V/ 90A Cree SiC MOSFET, 650V/ 50A Cree SiC Diode

1200V/ 100A Cree SiC MOSFET

Maximum power of $10 \mathrm{~kW}$ DC-DC converter in one The Łukasiewicz Research Network - Electrotechnical Institute

2020 [30] Haoran Li et.al, Nanjing University of Aeronautics and Astronautics

single module with $96.2 \%$ efficiency

Charge mode overall efficiency was greater than $96 \%$ over the entire battery voltage range. The power density reached $56 \mathrm{~W} / \mathrm{in}^{3}$.

\subsection{Motor Drives}

The importance of motor drive, especially in the industrial domain sparks an interest in improving and enhancing its capability to address the issues raised in various applications. Generally, things like efficiency, cost, and footprint/sizing always become a major concern for SiC-based motor drives. Medium voltage (MV) application motor drives are said to be more suitable to fully take advantage of SiC devices compared to low voltage type, in particular, taking into account the incorporation of high-speed medium voltage motors [31]. $\mathrm{SiC}$ power device offers a distinctive prospect to achieve a highly efficient motor drive with simpler topology. For example, SiC-based MV motor drives improve its efficiency by having a lesser loss of power semiconductors. Due to that, the aim of having simpler inverter topology is also achievable. Principally, higher power density is triggered by the high switching frequency, which allows MV direct drive variable speed controlled motor to abandon the usage of the gearbox. Therefore, causing a decent reduction in system size. A research work done by [32] is an example of how the SiC power device has made the aforementioned argument feasible. The 20kW MV motor drive is designed by adopting a two-level topology. It incorporates a $10 \mathrm{kV} / 10 \mathrm{~A} \mathrm{SiC} \mathrm{MOSFET} \mathrm{with} 6 \mathrm{kV}$ DC-link and $3.3 \mathrm{kV}$ line-to-line AC output which leads to the simplification of the drive topology. In-term of performance, efficiency, and power density are 
remarkably promising, estimated approaching $97 \%$ at $20 \mathrm{kHz}$ switching frequency and $4.11 \mathrm{~W} / \mathrm{inch} 3$, respectively. In 2019, Infineon Technologies has introduced in the market its EVAL-M5-E1B1245N evaluation board which is optimized for motor drive application. Table 3 tabulates a summary of other selected $\mathrm{SiC}$ power device contribution in a power drive application.

$\mathrm{SiC}$ devices have been deployed, investigated, and analyzed in different inverters by numerous researchers. For instance, a group of researchers in the United State [33],[34] have been working on a solar inverter that based on SiC Schottky diode which demonstrated the improvement of inverter's efficiency above $96 \%$ and reduced reverse recovery losses.

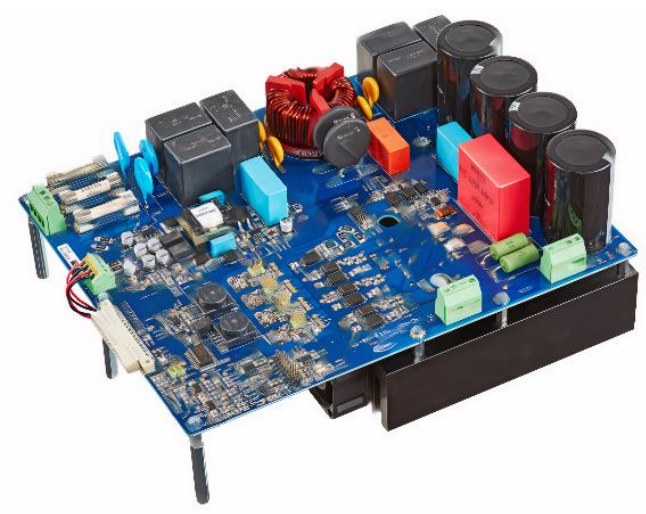

Figure 5: 7.5 kW EVAL-M5-E1B1245N-SiC motor driver [35]

Table 3: Summary of related research/development of sic devices in industrial motor drive applications

\begin{tabular}{|c|c|c|c|}
\hline $\begin{array}{l}\text { Commercial } \\
\text { or R\&D } \\
\text { Year }\end{array}$ & Developer/Researcher & Specification/performance & Approach \\
\hline $2007[36]$ & $\begin{array}{l}\text { Tiefu Zhao, North Carolina } \\
\text { State University }\end{array}$ & $\begin{array}{l}\text { At } 10 \mathrm{kHz} \text { switching frequency, } 68 \% \text { conduction loss } \\
\text { reduction, } 78 \% \text { switching loss reduction loss, } 99.1 \% \\
\text { system efficiency, and } 75 \% \text { heat sink size reduction. }\end{array}$ & $\begin{array}{l}\text { 1200V SiC MOSFET, } \\
\text { 1200V/ 20A SiC Schottky } \\
\text { diode }\end{array}$ \\
\hline 2014 [37] & $\begin{array}{l}\text { J. Colmenares et.al, KTH } \\
\text { Royal Institute of } \\
\text { Technology, Sweeden }\end{array}$ & $\begin{array}{l}99.3 \% \text { inverter efficiency at } 20 \mathrm{kHz} \text { switching frequency } \\
\text { over the entire load range. }\end{array}$ & $\begin{array}{l}1200 \mathrm{~V} / 168 \mathrm{~A} \mathrm{SiC} \\
\text { MOSFET }\end{array}$ \\
\hline $2015[38]$ & $\begin{array}{l}\text { Firus Zare et.al, Danfoss } \\
\text { Drives, Denmark }\end{array}$ & $\begin{array}{l}3 \% \text { efficiency improvement across wide power range (6- } \\
17 \mathrm{~kW} \text { ) compared to Si IGBT and } 18.5 \mathrm{~kW} \text { power at } 16 \\
\mathrm{kHz} \text { switching frequency }\end{array}$ & SiC MOSFET and SBD \\
\hline 2016 [39] & $\begin{array}{l}\text { Qin Haihong et.al, Nanjing } \\
\text { University of Aeronautics } \\
\text { and Astronautics }\end{array}$ & $\begin{array}{l}50 \% \text { power loss reduction, system efficiency increased } \\
\text { by } 1 \% \text { compared to Si-based system, and heat sink } \\
\text { temperature reduction by } 3^{\circ} \mathrm{C}\end{array}$ & $\begin{array}{l}1200 \mathrm{~V} / 24 \mathrm{~A} \mathrm{SiC} \\
\text { MOSFET }\end{array}$ \\
\hline $2016[40]$ & $\begin{array}{l}\text { S. Tiwari et.al, Norwegian } \\
\text { University of Science and } \\
\text { Technology }\end{array}$ & $\begin{array}{l}\text { System efficiency } 98.7 \% \text { at } 20 \mathrm{kHz} \text { switching frequency, } \\
\text { and } 71 \% \text { switching losses reduction. }\end{array}$ & $\begin{array}{l}\text { 1200V/ 50A SiC } \\
\text { MOSFET }\end{array}$ \\
\hline $2018[41]$ & $\begin{array}{l}\text { A. Kempitita et.al, Infineon } \\
\text { Technologies America Corp. }\end{array}$ & Semiconductor power loss reduction up to $30 \%$ & $1200 \mathrm{~V} \mathrm{SiC} \mathrm{MOSFET}$ \\
\hline $2019[42]$ & $\begin{array}{l}\text { O. Sivkov et.al, Czech } \\
\text { Technical University }\end{array}$ & $\begin{array}{l}\text { Switching slew rate two times higher compared to } \mathrm{Si} \\
\text { IGBT's. }\end{array}$ & $\begin{array}{l}1200 \mathrm{~V} / 50 \mathrm{~A} \mathrm{SiC} \\
\text { MOSFET }\end{array}$ \\
\hline 2019 [43] & $\begin{array}{l}\text { J. Loncarski et.al, Upsala } \\
\text { University, Sweden }\end{array}$ & $\begin{array}{l}27 \% \text { conduction loss reduction at } 60 \mathrm{kHz} \text { switching } \\
\text { frequency and overvoltage peak reduction by } 71 \%\end{array}$ & $1200 \mathrm{~V} \mathrm{SiC} \mathrm{MOSFET}$ \\
\hline
\end{tabular}

\subsection{Solar inverter}

With the remarkable performance of the $\mathrm{SiC}$ power device, it is the best candidate in the applications where efficiency, power density, cost, and speed are the ultimate concern. One of them is the solar inverter. The capability to reach higher efficiency in the energy conversion process is directly proportional to the cost reduction i.e. reduced solar panel area, simpler circuitry/topology, and even lower installation fee [7], [44]. Furthermore, in the past few years, a group of GE's researchers and engineers have been working on a single-stage megawatt level solar inverter [45]. The inverter integrates an advanced $\mathrm{SiC}$ MOSFET module with an innovative system engineering design. As a result, at $900 \mathrm{~V}$ dc input, the California 
energy commission (CEC) efficiency of the inverter is reaching close to 99\%. Figure 6 and Figure 7 illustrate the efficiency of GE SiC megawatt solar inverter and GE's LV5+ SiC-based solar inverter, respectively. Table 4 summarizes several selected researches works on $\mathrm{SiC}$ devices in the emerging solar inverter applications for the past few years.

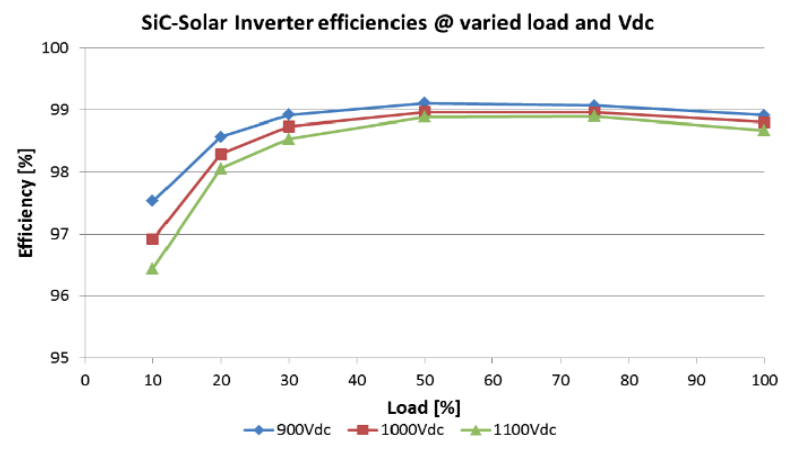

Figure 6: Efficiency of GE SiC megawatt solar inverter [45]

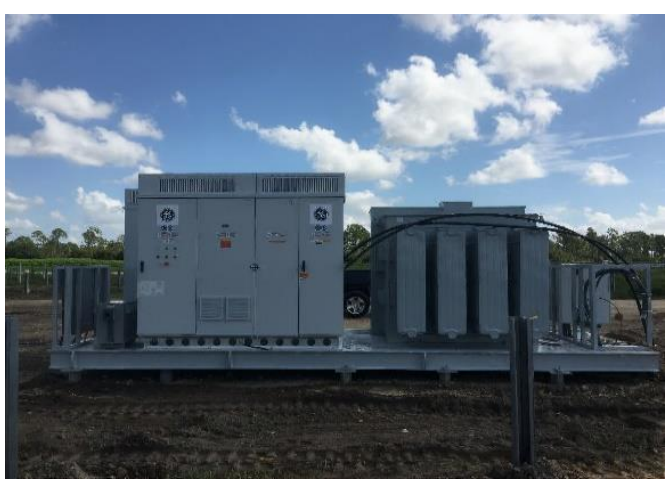

Figure 7: GE's LV5+ SiC-based solar inverter with $99 \%$ weighted EU efficiency [46]

Table 4: Summary of related research/development of Sic devices in solar inverter applications

\begin{tabular}{|c|c|c|c|}
\hline $\begin{array}{l}\text { Commercial } \\
\text { or R\&D } \\
\text { Year }\end{array}$ & Developer/Researcher & Specification/performance & Approach \\
\hline 2014 [47] & $\begin{array}{l}\text { U. Schwarzer et.al, Infineon } \\
\text { Technologies AG }\end{array}$ & $\begin{array}{l}29.7 \% \text { system power loss reduction for a } 2 \text {-level inverter } \\
\text { with } 18 \% \text { system cost-saving, and } 47.9 \% \text { system power } \\
\text { loss reduction for a } 3 \text {-level inverter with } 20 \% \text { system } \\
\text { cost saving. }\end{array}$ & $\begin{array}{l}\text { 1200V/ 45A SiC JFET, } \\
\text { 1200V/ 60A SiC JFET, } \\
\text { 600V SiC Diode }\end{array}$ \\
\hline $2015[48]$ & $\begin{array}{l}\text { K. Fujii et.al, Fuji Electric } \\
\text { Co. Ltd }\end{array}$ & $\begin{array}{l}\text { Switching slew rate reduced } 10 \% \text { compared to Si IGBT, } \\
\text { current unbalance ratio is less than } 7.5 \% \text { of the nominal } \\
\text { output current, and maximum efficiency is } 9808 \% \text { with } \\
\text { the EU average by } 0.5 \% \text { compared to conventional } \\
\text { single-stage inverter. }\end{array}$ & $\begin{array}{l}1200 \mathrm{~V} / 100 \mathrm{~A} \text { SiC } \\
\text { MOSFET \& SBD }\end{array}$ \\
\hline 2015 [49] & $\begin{array}{l}\text { A. Hensel et.al, Institute for } \\
\text { Solar Energy System, } \\
\text { Fraunhofer ISE }\end{array}$ & $\begin{array}{l}\text { Inverter efficiency exceeds } 98 \% \text { at } 48 \mathrm{kHz} \text { switching } \\
\text { frequency }\end{array}$ & $\begin{array}{l}1200 \mathrm{~V} / 55 \mathrm{~A} \text { and } 1200 \mathrm{~V} \\
124 \mathrm{~A} \mathrm{SiC} \mathrm{MOSFET}\end{array}$ \\
\hline $2016[50]$ & $\begin{array}{l}\text { A. Hatanaka et.al, Hitachi } \\
\text { Ltd }\end{array}$ & $\begin{array}{l}\text { Peak inverter efficiency exceeds } 99.1 \% \text { within a } 30-60 \% \\
\text { load factor. } 65 \% \text { reduction in current deviation compared } \\
\text { to Si IGBT }\end{array}$ & SiC MOSFET \\
\hline $2016[51]$ & $\begin{array}{l}\text { S. Wall et.al, Clenergy } \\
\text { International Ltd }\end{array}$ & $\begin{array}{l}\text { Inverter efficiency improved by } 0.3 \% \text { to } 98 \% \text { CEC } \\
\text { weighted-average efficiency }\end{array}$ & $1200 \mathrm{~V} / 200 \mathrm{~A}$ SiC diode \\
\hline $2017[52]$ & $\begin{array}{l}\text { A. Anthon et.al, Technical } \\
\text { University of Denmark }\end{array}$ & $\begin{array}{l}\text { Semiconductor losses reduce by more than } 50 \% \\
\text { converter efficiency increase by } 1 \% \text { at light load, over } \\
60 \% \text { reduction in cooling requirement at } 192 \mathrm{kHz} \\
\text { switching frequency }\end{array}$ & 1200V SiC MOSFET \\
\hline $2017[53]$ & $\begin{array}{l}\text { F. Remi et.al, Fraunhofer } \\
\text { ISE }\end{array}$ & $\begin{array}{l}\text { Peak efficiencies are } 99.1 \% \text { and } 99.0 \% \text { for booster stage } \\
\text { and inverter stage, respectively, at } 96 \mathrm{kHz} \text { and } 48 \mathrm{KHz} \\
\text { switching frequency. Overall European average } \\
\text { efficiency is } 98.4 \text { and reaches up to } 9807 \% \text { at the peak. } \\
\text { Improvement of power density up to } 50 \% \text { and } 70 \% \\
\text { saving in-term of cost. }\end{array}$ & 1200V SiC MOSFET \\
\hline $2019[54]$ & $\begin{array}{l}\text { M. Ahmed et.al, Chongqing } \\
\text { University }\end{array}$ & $\begin{array}{l}\text { The efficiency increases to } 99.2 \% \text { from its initial } 95.2 \% \\
\text { at a various output power }\end{array}$ & $\begin{array}{l}\text { 1200V/ 19A SiC MOSFET } \\
\text { and SBD diode }\end{array}$ \\
\hline $2019[55]$ & $\begin{array}{l}\text { Xu She et.al, United } \\
\text { Technologies Corp }\end{array}$ & CEC average efficiency is more than $99 \%$ & 1200V SiC MOSFET \\
\hline
\end{tabular}

\section{CHALLENGES}

Although comes to the market with the appealing characteristic and performance, there are still many challenges raised from the device and application point of views which require close attention from the developer as well as end-users [3].

The gate driver design is likely to be more challenging for $\mathrm{SiC}$ devices due to the occurrence of the positive counterfeit voltage gate [56]. This is due to the higher dv/dt of the SiC devices which imposes higher

Silicon carbide power device characteristics, applications and challenges ... (Muhamad Faizal Yaakub) 
common mode current to be injected to the gate loop. Consideration to have an advanced gate driver with $\mathrm{dv} / \mathrm{dt}$ and/or di/dt control is a must. Since SiC devices also hold a faster current rise during fault events, therefore a faster response protection requirement is indispensable. Nevertheless, timing mismatch caused by parallel or/and series also must be taken into consideration in the system design.

Some high voltage and high power applications that adopt SiC devices may face severe electromagnetic interference (EMI) noise because of the high $\mathrm{dv} / \mathrm{dt}$ formed by the huge parasitic capacitance and fast switching speed. An appropriate EMI filter is necessary for motor drive applications to prevent the occurrence of voltage doubling effect caused by the high dv/dt. Similarly, extreme EMI conduction caused by high dv/dt will appear on the grid side in the grid-connected application. Therefore, the EMI filter is indispensable and advanced technology of EMI suppression method is also crucial to be investigated [57],[58].

Long term reliability of the SiC devices across all applications must vividly be demonstrated. This is vital for applications that are sensitive and extremely critical such as aviation, space program, and military [59]. The thermal ripple coming from the SiC-based converter is possibly larger than the $\mathrm{Si}$ converter due to its capability in providing a higher current rating. Consequently, a more rigid specification for package materials is compulsory as the $\mathrm{SiC}$ device operates at higher temperature conditions. Then again, due to SiC devices' capability operates in high-temperature conditions, peripheral components associated with it become crucial, especially the capacitors because connectors linking high-temperature devices to the capacitor may further raise the capacitor's temperature [60].

The full potential of the $\mathrm{SiC}$ device somehow cannot be achieved due to the packaging limitation [61]. As such it must be justified that the manufacturing for both front end and back-end processes must be improved to address the challenge. Since 2012, most major semiconductor and their silicon foundry companies have moved towards $150 \mathrm{~mm}$ wafer fabrication which allows more dies to be planted. As such, lower cost per each device is achievable

\section{CONCLUSION}

Silicon Carbide devices including MOSFET, diode, and other unipolar/bipolar switches are well accepted in the high-performance power electronics application. This due to its capability in yielding a remarkable benefit to at least in three following aspects; Noticeable reduction in power loss which leads to simplification of cooling requirement and poses higher system efficiency. Overall system improvement stimulated by high switching frequency and wide bandwidth control capability. Simplification and optimization of system circuitry and topology especially for converters.

However, $\mathrm{SiC}$ advancement characteristic brings several challenges to the device's applications, including gate driver design, electromagnetic interference, reliability, and manufacturing/process. Some of the arguments presented in this paper are yet to be solved and active research is ongoing. No doubt that the continuous improvement of $\mathrm{SiC}$ technologies is crucial for it to be implemented in far-reaching applications

\section{ACKNOWLEDGMENTS}

The author would like to acknowledge the Universiti Teknikal Malaysia Melaka and Universiti Putra Malaysia for their financial and technical support.

\section{REFERENCES}

[1] H. Zhang and L. M. Tolbert, "Efficiency impact of silicon carbide power electronics for modern wind turbine full scale frequency converter," IEEE Trans. Ind. Electron., vol. 58, no. 1, pp. 21-28, 2011.

[2] J. Millan, P. Godignon, X. Perpina, A. Perez-Tomas, and J. Rebollo, "A survey of wide bandgap power semiconductor devices," IEEE Trans. Power Electron., vol. 29, no. 5, pp. 2155-2163, 2014.

[3] M. Rosina, "GaN and SiC power device : market overview Remaining challenges," Semicon Eur., 2018.

[4] S. Krishnamurthy, R. Kannan, C. C. Kiong, T. B. Ibrahim, and Y. Abdullah, "Impact of gamma-ray irradiation on dynamic characteristics of Si and SiC power MOSFETs," Int. J. Electr. Comput. Eng., vol. 9, no. 2, pp. 14531460, 2019.

[5] D. Grider et al., "10 kV/120 A SiC DMOSFET half H-bridge power modules for $1 \mathrm{MVA}$ solid state power substation,” 2011 IEEE Electr. Sh. Technol. Symp. ESTS 2011, pp. 131-134, 2011.

[6] B. J. Baliga, Fundamentals of Power Semiconductor Devices. Springer, 2010.

[7] D. C. Sheridan, A. Ritenour, R. Kelley, V. Bondarenko, and J. B. Casady, "Advances in SiC VJFETs for renewable and high-efficiency power electronics applications,” 2010 Int. Power Electron. Conf. - ECCE Asia -, IPEC 2010, pp. 3254-3258, 2010.

[8] S. Ji, Z. Zhang, and F. Wang, "Overview of high voltage sic power semiconductor devices: development and 
application," CES Trans. Electr. Mach. Syst., vol. 1, no. 3, pp. 254-264, 2017.

[9] K. Puschkarsky, T. Grasser, T. Aichinger, W. Gustin, and H. Reisinger, "Review on SiC MOSFETs High-Voltage Device Reliability Focusing on Threshold Voltage Instability," IEEE Trans. Electron Devices, vol. 66, no. 11, pp. 4604-4616, 2019.

[10] N. P. Maity, "4H-SiC Semiconductor based Metal Oxide Semiconductor Devices," 2011 Int. Conf. Futur. Inf. Technol., vol. 13, no. June, pp. 265-269, 2011.

[11] H. Jain, S. Rajawat, and P. Agrawal, Comparision of wide band gap semiconductors for power electronics applications. 2003.

[12] K. Shenai, R. S. Scott, and B. J. Baliga, "Optimum semiconductors for high-power electronics," IEEE Trans. Electron Devices, vol. 36, no. 9, pp. 1811-1823, 1989.

[13] S. Yin, K. J. Tseng, R. Simanjorang, Y. Liu, and J. Pou, "A 50-kW High-Frequency and High-Efficiency SiC Voltage Source Inverter for More Electric Aircraft," IEEE Trans. Ind. Electron., vol. 64, no. 11, pp. 9124-9134, 2017.

[14] A. Ajanovic, "The future of electric vehicles: Prospects and impediments," Wiley Interdiscip. Rev. Energy Environ., 2015.

[15] S. K. Yadav, "Electrical Car/Vehicle: Future Prospects for Electromobility," Int. J. Sci. Eng. Res., vol. 4, no. 9, pp. 660-667, 2013.

[16] A. Kumar and L. B. Prasad, "Issues, challenges and future prospects of electric vehicles: A review," 2018 Int. Conf. Comput. Power Commun. Technol. GUCON 2018, pp. 1060-1065, 2019.

[17] X. She, A. Q. Huang, O. Lucia, and B. Ozpineci, "Review of Silicon Carbide Power Devices and Their Applications," IEEE Trans. Ind. Electron., vol. 64, no. 10, pp. 8193-8205, 2017.

[18] Yole Group of Companies, "Automotive is driving SiC adoption," Power SiC 2018 Mater. Devices Appl., pp. 1-5, 2018.

[19] K. Akatsu, N. Watanabe, M. Fujitsuna, S. Doki, and H. Fujimoto, "Recent related technologies for EV/HEV applications in JAPAN," 2013 IEEE ECCE Asia Downunder - 5th IEEE Annu. Int. Energy Convers. Congr. Exhib. IEEE ECCE Asia 2013, pp. 141-146, 2013.

[20] T. M. Corporation, "Toyota to Trial New SiC Power Semiconductor Technology," 2015. [Online]. Available: https://global.toyota/en/detail/5692153.

[21] H. Zhang, L. M. Tolbert, and B. Ozpineci, "Impact of SiC devices on hybrid electric and plug-in hybrid electric vehicles," Conf. Rec. - IAS Annu. Meet. (IEEE Ind. Appl. Soc., no. 1, pp. 1-5, 2008.

[22] M. Chinthavali, L. M. Tolbert, H. Zhang, J. H. Han, F. Barlow, and B. Ozpineci, "High power SiC modules for HEVs and PHEVs," 2010 Int. Power Electron. Conf. - ECCE Asia -, IPEC 2010, vol. 6, pp. 1842-1848, 2010.

[23] M. Su, C. Chen, S. Sharma, and J. Kikuchi, "Performance and cost considerations for SiC-based HEV traction inverter systems," WiPDA 2015 - 3rd IEEE Work. Wide Bandgap Power Devices Appl., pp. 347-350, 2015.

[24] D. Rahman et al., "Design methodology for a planarized high power density EV/HEV traction drive using SiC power modules," ECCE 2016 - IEEE Energy Convers. Congr. Expo. Proc., pp. 1-7, 2016.

[25] F. Wada, N. Miyamoto, K. Yoshida, and S. Godo, "6-in-1 Silicon Carbide (SiC) MOSFET Power Module for EV/HEV inverters," PCIM Asia 2017; Int. Exhib. Conf. Power Electron. Intell. Motion, Renew. Energy Energy Manag., no. June, pp. 1-4, 2017.

[26] J. Liu, W. Su, X. Tai, W. Sun, L. Gu, and X. Wen, "Development of an inverter using hybrid SIC power module for EV/HEV applications," 19th Int. Conf. Electr. Mach. Syst. ICEMS 2016, pp. 1-5, 2017.

[27] F. E. Alfaris and S. Bhattacharya, "A current-fed quasi Z-Source inverter with SiC power modules for EV/HEV applications,” 2017 IEEE Energy Convers. Congr. Expo. ECCE 2017, vol. 2017-Janua, pp. 5445-5452, 2017.

[28] W. Zhou, Q. Guo, X. Wu, Y. Liu, and K. Sheng, "A 1200V/100A all-SiC power module for boost converter of EV/HEV's motor driver application," 2016 Int. Forum Wide Bandgap Semicond. China, IFWS 2016 - Conf. Proc., no. 38 , pp. $38-41,2017$.

[29] A. J. Moradewicz, R. M. Miskiewicz, M. Parchomiuk, and T. Sak, "Research of SIC Solid State Transformer Model for Electric Vehicles Chargers Applications," 2019 Prog. Appl. Electr. Eng. PAEE 2019, pp. 2-5, 2019.

[30] H. Li et al., "A 300-kHz 6.6-kW SiC Bidirectional LLC Onboard Charger," IEEE Trans. Ind. Electron., vol. 67, no. 2, pp. 1435-1445, 2020.

[31] H. L. Uhg, D. Q. J. Dqg, and K. H. X. Kdqj, "Overview of Silicon Carbide Technology : Device, Converter, System, and Application," CPSS Trans. Power Electron. Appl., vol. 1, no. 1, pp. 13-32, 2016.

[32] S. Madhusoodhanan, K. Mainali, A. Tripathi, K. Vechalapu, and S. Bhattacharya, "Medium voltage ( $\geq 2.3 \mathrm{kV})$ high frequency three-phase two-level converter design and demonstration using $10 \mathrm{kV} \mathrm{SiC} \mathrm{MOSFETs} \mathrm{for} \mathrm{high}$ speed motor drive applications," Conf. Proc. - IEEE Appl. Power Electron. Conf. Expo. - APEC, vol. 2016-May, pp. 1497-1504, 2016.

[33] X. She, P. Losee, H. Hu, W. Earls, and R. Datta, "Evaluation of $2.5 \mathrm{kV}$ Silicon Carbide MOSFET for $1.5 \mathrm{kV}$ Solar Inverter Application," 2018 IEEE Energy Convers. Congr. Expo. ECCE 2018, pp. 2516-2523, 2018.

[34] B. Chen, B. Gu, L. Zhang, and J. S. Lai, "A Novel Pulse-Width Modulation Method for Reactive Power Generation on a CoolMOS- and SiC-Diode-Based Transformerless Inverter," IEEE Trans. Ind. Electron., vol. 63, no. 3, pp. 1539-1548, 2016.

[35] A. KALNOSKAS, "SiC eval board drives $7.5 \mathrm{~kW}$ motors for industrial drive apps," Power Electronic Tips, 2019. [Online]. Available: https://www.powerelectronictips.com/sic-eval-board-drives-7-5-kw-motors-for-industrialdrive-apps/.

[36] T. Zhao, J. Wang, A. Q. Huang, and A. Agarwal, "Comparisons of SiC MOSFET and Si IGBT based motor drive systems," Conf. Rec. - IAS Annu. Meet. (IEEE Ind. Appl. Soc., pp. 331-335, 2007. 
[37] J. Colmenares, D. Peftitsis, G. Tolstoy, D. Sadik, H. P. Nee, and J. Rabkowski, "High-efficiency three-phase inverter with $\mathrm{SiC}$ MOSFET power modules for motor-drive applications," 2014 IEEE Energy Convers. Congr. Expo. ECCE 2014, pp. 468-474, 2014.

[38] F. Zare, D. Kumar, M. Lungeanu, and A. Andreas, "Electromagnetic interference issues of power, electronics systems with wide band gap, semiconductor devices," 2015 IEEE Energy Convers. Congr. Expo. ECCE 2015, pp. 5946-5951, 2015.

[39] H. Qin, H. Xie, Z. Ziyue, N. Xin, H. Xu, and D. Fu, "Comparisons of SiC and Si devices for PMSM drives," 2016 IEEE 8th Int. Power Electron. Motion Control Conf. IPEMC-ECCE Asia 2016, pp. 891-896, 2016.

[40] S. Tiwari, O. M. Midtgard, and T. M. Undeland, "SiC MOSFETs for future motor drive applications," 2016 18th Eur. Conf. Power Electron. Appl. EPE 2016 ECCE Eur., no. September 2016, 2016.

[41] A. Kempitiya and W. Chou, "An electro-thermal performance analysis of SiC MOSFET vs Si IGBT and diode automotive traction inverters under various drive cycles," 34th Annu. Semicond. Therm. Meas. Manag. Symp. SEMI-THERM 2018 - Proc., pp. 213-217, 2018.

[42] O. Sivkov, M. Novak, and J. Novak, "Comparison between Si IGBT and SiC MOSFET Inverters for AC Motor Drive,” Proc. 2018 18th Int. Conf. Mechatronics - Mechatronika, ME 2018, pp. 1-5, 2019.

[43] J. Loncarski, V. G. Monopoli, R. Leuzzi, and F. Cupertino, "Operation analysis and comparison of Multilevel Si IGBT and 2-level SiC MOSFET inverter-based high-speed drives with long power cable," ICCEP 2019 - 7th Int. Conf. Clean Electr. Power Renew. Energy Resour. Impact, pp. 503-509, 2019.

[44] Z. Zeng et al., "Changes and challenges of photovoltaic inverter with silicon carbide device," Renew. Sustain. Energy Rev., vol. Volume 78, pp. 624-639, 2017.

[45] M. H. Todorovic et al., "SiC MV PV Inverter," PCIM Eur. 2016; Int. Exhib. Conf. Power Electron. Intell. Motion, Renew. Energy Energy Manag., no. May, pp. 10-12, 2016.

[46] M. Osborne, "GE's advanced silicon carbide technology at core of next-gen 1500 volt central inverter," $p v-$ tech.org, 2016. [Online]. Available: https://www.pv-tech.org/products/ges-advanced-silicon-carbide-technology-atcore-of-next-gen-1500-volt-centr.

[47] U. Schwarzer, S. Buschhorn, and K. Vogel, "System benefits for solar inverters using SiC semiconductor modules," PCIM Eur. Conf. Proc., no. May, pp. 787-794, 2014.

[48] K. Fujii, Y. Noto, M. Oshima, and Y. Okuma, "1-MW solar power inverter with boost converter using all SiC power module," 2015 17th Eur. Conf. Power Electron. Appl. EPE-ECCE Eur. 2015, pp. 1-10, 2015.

[49] A. Hensel, C. Gasser, C. Schoner, and A. H. Wienhausen, "Integrated three-phase PV SiC inverter to increase selfconsumption with innovative topology, flexible connection options and high efficiency," 2015 17th Eur. Conf. Power Electron. Appl. EPE-ECCE Eur. 2015, 2015.

[50] A. Hatanaka, H. Kageyama, and T. Masuda, "A 160-kW high-efficiency photovoltaic inverter with paralleled SiCMOSFET modules for large-scale solar power," INTELEC, Int. Telecommun. Energy Conf., vol. 2016-Septe, pp. $1-5,2016$

[51] S. Wall, X. C. Hong, L. Sha, and J. R. Xie, "High-efficiency PV inverter with SiC technology," IET Renew. Power Gener., vol. 12, no. 2, pp. 149-156, 2018.

[52] A. Anthon, Z. Zhang, M. A. E. Andersen, D. G. Holmes, B. McGrath, and C. A. Teixeira, "The benefits of SiC mosfets in a T-type inverter for grid-tie applications," IEEE Trans. Power Electron., vol. 32, no. 4, pp. 2808-2821, 2017.

[53] F. Rémi, F. Sebastian, F. Marc, and L. Stephan, "A $70 \mathrm{~kW}$ next generation three-phase solar inverter with multiple MPPTs using advanced cooling concept and stacked-PCB architecture," PCIM Eur. 2017 - Int. Exhib. Conf. Power Electron. Intell. Motion, Renew. Energy Energy Manag., vol. 2, no. May, pp. 16-18, 2017.

[54] M. H. Ahmed, M. Wang, M. A. S. Hassan, and I. Ullah, "Power Loss Model and Efficiency Analysis of ThreePhase Inverter Based on SiC MOSFETs for PV Applications," IEEE Access, vol. 7, pp. 75768-75781, 2019.

[55] X. She, P. Losee, H. Hu, W. Earls, and R. Datta, "Performance Evaluation of $1.5 \mathrm{kV}$ Solar Inverter with $2.5 \mathrm{kV}$ Silicon Carbide mosfet," IEEE Trans. Ind. Appl., vol. 55, no. 6, pp. 7726-7735, 2019.

[56] J. Hu et al., "Robustness and Balancing of Parallel-Connected Power Devices: SiC Versus CoolMOS," IEEE Trans. Ind. Electron., vol. 63, no. 4, pp. 2092-2102, 2016.

[57] X. Gong and J. A. Ferreira, "Investigation of conducted EMI in SiC JFET inverters using separated heat sinks," IEEE Trans. Ind. Electron., vol. 61, no. 1, pp. 115-125, 2014.

[58] L. Zhai, X. Zhang, X. Gao, G. Lee, M. Zou, and T. Sun, "Impact of distributed parameters on conducted EMI in electric vehicles motor drive system," Energy Procedia, vol. 88, pp. 860-866, 2016.

[59] A. Bolotnikov et al., "Overview of $1.2 \mathrm{kV}-2.2 \mathrm{kV} \mathrm{SiC} \mathrm{MOSFETs} \mathrm{targeted} \mathrm{for} \mathrm{industrial} \mathrm{power} \mathrm{conversion}$ applications," Conf. Proc. - IEEE Appl. Power Electron. Conf. Expo. - APEC, vol. 2015-May, no. May, pp. 2445$2452,2015$.

[60] F. Wang, D. Boroyevich, R. Burgos, K. Karimi, V. D. Immanuel, and E. V Solodovnik, "High-Temperature Hardware: Development of a 10-kW High-Temperature, High-Power-Density Three-Phase ac-dc-ac SiC Converter," IEEE Ind. Electron. Mag., vol. 7, no. 1, pp. 6-17, 2013.

[61] C. Chen, "A Review of SiC Power Module Packaging: Layout, Material System and Integration," CPSS Trans. Power Electron. Appl., vol. 2, no. 3, pp. 170-186, 2017. 